\title{
The entrapment of asymmetry: the Philippines between the US and China
}

\author{
Elaine Tolentino ${ }^{1 *}$ and Myungsik Ham²
}

\author{
${ }^{*}$ Correspondence: \\ elaine.tolentino@dlsu.edu.ph \\ ${ }^{1}$ International Studies \\ Department, De La Salle \\ University, Manila, Philippines \\ Full list of author information \\ is available at the end of the \\ article
}

\begin{abstract}
This paper aims to analyze the asymmetric dilemma facing the Philippines and China in the South China Sea tensions. Among American East Asian allies, the Philippines seems to stand on the frontline between two rival powers, the United States and China. Since the US declared its Pivot to Asia policy, the Philippines'foreign policy towards China has become assertive and sometimes appears reckless with some military adventures against Chinese maritime patrols and naval ships, which also further forced China to take a tougher foreign policy against the Philippines. Considering the distinctive asymmetric indicators between China and the Philippines based on military forces, economic capacity, territorial size, and population, the aggressive policy behaviors that the Philippines and China have been displaying against each other cast an inquiry on what drives the two countries into head-to-head collision. While China as the larger power vis-à-vis the Philippines as the smaller power in the relationship has aimed for control and domination of their disputed territory, the Philippines' drastic defiance has also led to China's irritation and possible frustration. Furthermore, the US'renewed attention to Asia has caused shifts of asymmetric bilateral dilemma to triangular entanglement between the US-China-Philippines. It is vital therefore to pay attention to the asymmetric interaction of states and their varying views in order to find possible solutions to the SCS tensions.
\end{abstract}

Keywords: Asymmetry, South China Sea disputes, Philippines, China, United States

\section{Background}

Two decades ago, international relations scholars from the United States have contended that East Asia is "ripe for rivalry" (Friedberg 1993). At present, this prediction seems to be in the offing. The several decades long territorial dispute in the South China Sea between China, the Philippines, Vietnam, Malaysia and Taiwan has reawakened to frequent tussles between China and Vietnam and military stand-offs between China and the Philippines. With China's growing military strength comes a more assertive stance in the region. Its claims to the U-shaped area has fueled a vicious cycle of provocations not just with its ASEAN neighbors but also more confrontational exchange of words between the US and China. The SCS dispute has further compounded the already complex relationship between the two big powers as the issue has elevated their battle for influence to maritime competition in the Southeast Asian region.

While Beijing has been insistent on bilateral negotiations with individual claimant countries to manage the issue, ASEAN countries are all too aware of their vulnerabilities

(C) 2015 Tolentino and Ham. This article is distributed under the terms of the Creative Commons Attribution 4.0 International License (http://creativecommons.org/licenses/by/4.0/), which permits unrestricted use, distribution, and reproduction in any medium, provided you give appropriate credit to the original author(s) and the source, provide a link to the Creative Commons license, and indicate if changes were made. 
in dealing with China bilaterally due to different state capacity caused by military and economic power, territorial size, population and international influence. Instead, China's smaller neighbors chose an alternative to handle the SCS issue and particularly, the Philippines has opted to use a multilateral framework through a UN Tribunal Court to challenge China's claims. Manila's growing confidence in pushing forward its case against Beijing has been bolstered by Washington's declaration of its "pivot" to Asia during President Barack Obama's November 2011 speech in Darwin to safeguard both US economic and security interests and concerns in the region. ${ }^{1}$ The US pivot or rebalancing in Asia has since been signified by the US' increased participation in multilateral trade agreements, joint military exercises with the Philippines and Vietnam, and high diplomatic visits and exchanges, and they further increased China's worries of US encroachment in its own backyard. Considering the disparity in state capacity between China and the Philippines and the more complex but still asymmetric relationship between the US and China, this paper tackles these issues and probes the following questions. What causes the head-to-head confrontational behavior of states in asymmetric relationships in the region? How do states' asymmetric interactions affect the heightening frictions in the SCS? In other words, this article analyzes the dynamics of asymmetric interactions and their relevance to the SCS disputes.

Scholars of international relations and analysts closely watching the escalating tensions in the SCS have come up with a plethora of convincing arguments to examine the dilemma mostly from the side of the bigger power, China, who has the largest claims to the area. Many analysts assert that Beijing's "bullying" of its smaller neighbors stems from several factors, such as the shifting balance of power moving to its favor, the rising military strength of its naval power and expanding national interests, and the country's heightened nationalism (Cha 2012; Dutton 2011; French 2014; Yahuda 2013). Others, however, argue that Washington's rebalancing the Asia-Pacific policy in response to China's rise is seen by the latter as part of the former's containment strategy, which causes a reactionary China to worry and take a more assertive policy (Ratner 2013). Still, a few contend that the more assertive actions taken by smaller states, particularly from the Philippines' use of the Washington card to confront China's expansion, is necessary to face a rising threat (De Castro 2014) but could further tensions in the region (Glaser 2012). While all of these views are accurate in their rationalizations, their explanations lack a thorough account of the rising regional tension by simultaneously locating different players' perspectives arising from their asymmetric interactions. The contribution of this paper to these debates is to provide a normative analysis of the dispute by giving meaning to the asymmetric dilemmas facing different players in the Southeast Asian region, in this case, between China and the Philippines, and its ramifications to US-China relations. This is particularly significant because its focus is on the idea of the relational aspect or the two sides of the asymmetric interactions that shape the current situation in the SCS, whereas previous debates mainly focus on one side of the equation.

This paper, therefore, aims to analyze the asymmetric dilemmas facing the Philippines and China in the SCS tensions. Among American East Asian allies, the Philippines

${ }^{1}$ Associated Press in Canberra, November 17, 2011, "Obama tells Asia US 'here to stay' as a Pacific power". http://www. theguardian.com/world/2011/nov/17/obama-asia-pacific-address-australia-parliament. 
seems to stand on the frontline between two rival powers, the US and China. Since the US declared its Pivot to Asia policy, the Philippines' foreign policy towards China has become assertive and sometimes appears reckless with some military adventures against Chinese maritime patrols and naval ships, which also further forced China to take a tougher foreign policy against the Philippines. Considering the distinctive asymmetric indicators between China and the Philippines based on military forces, economic capacity, territorial size, and population, the aggressive policy behaviors that the Philippines and China have been displaying against each other cast an inquiry of what drives the two countries towards a head-to-head collision.

While China as the larger power vis-à-vis the Philippines as the smaller power in the relationship has aimed for control and domination of their disputed territory, the Philippines' drastic defiance has also led to China's irritation and possible frustration. Paying attention therefore to the asymmetric interaction of states and their varying views is vital in order to find possible solutions to the SCS tensions. We argue that the rising tensions in the South China Sea is due to the failed management of asymmetric international relationships. The next section of this paper provides a brief discussion of previous scholarly works with respect to the South China Sea disputes. Then, it presents an analytic framework of asymmetry to account for the reasons of escalating suspicion and conflict between China and the Philippines from a regional level and how it interrelates to the triangular asymmetric relations in a global level. The third section describes the method and case selection of the paper. In the fourth section, it examines details of the recent interactions between China and the Philippines from 2011 to the present that cause the asymmetric dilemma to spiral. In the final analysis, it discusses how the US' renewed attention to Asia causes shifts of asymmetric bilateral dilemma to triangular entanglement between the US-China-Philippines.

\section{Previous studies on the South China Sea disputes}

The conflict in the South China Sea is neither an outcome of the rise of China nor the return of the US to the Asia Pacific. For centuries, countries have wrestled for their rights to the area. Today, the two main flashpoints of territorial sovereignty are the island chains of the Spratlys and the Paracels and the Scarborough Shoal. The recent tensions in the SCS have been frequently on the radar of newsprints, the media, government think-tanks, academia, and policy analysts. Scholarly articles, books, and policy papers analyzing the recent tensions have flourished, inflaming the debates on the causes of the tensions and its implications to the stability of the East Asian region. Most of these studies, for obvious reasons, have focused on China's increasingly aggressive foreign policy behavior in the SCS from external and internal sources, how it affects its relations with individual claimant countries or with ASEAN in general, and implications for US-China relations. These perspectives can be broadly categorized into three: realist assessments, which posit the significance of the material dimensions and changes in the international structure; the domestic political approach based on the role of nationalism; and the normative solution process through the UNCLOS.

\section{Realism}

Realist views of global politics contend that the anarchical nature of the world is a basic given that drives states into a constant struggle for security and survival. Sates perceive 
other states as a conceivable threat so they always worry about their relative positions in the international system. As states worry about their relative positions, it becomes their incessant preoccupation to accumulate wealth and military power not just to maintain their present positions but to ensure their future. Just as Kenneth Waltz explains (1993: 60), "Uncertainty is a synonym of life, and nowhere is uncertainty greater than in international politics.... If one cannot know what is coming, developing a greater resource base for future use takes precedence over present prosperity." In the post-Cold War period, the re-emergence of China and the relative decline of the US reflect the shifting international power distribution, which also modifies states' behavior in response to the changing distribution.

From the point of view of territorial disputes, this section synthesizes realist accounts of the sources of states' varying responses in relation to their relative positions in the system. From the perspective of China, in particular, scholars argue that the factor of rising China works as a critical cause leading to its more aggressive behavior in the SCS. Yahuda (2013), for instance, provides a comprehensive explanation of the changes from the international and internal environments that leads China to be more assertive in the SCS: from the shifting balance of power, China's expanding interests to maritime interests, a growing naval military power, and increasing nationalism. The shifting balance of power arising from China's ascendancy as an economic power results in the enlargement of its national interests now including its maritime interests. However, he emphasizes that the growth of China's naval power and its insistent claims will make it more problematic to find an immediate solution to the issue.

Other scholars argue that China's continuously growing economy leads to its rising energy demands, which puts more pressure on China's state leaders to find and diversify its energy sources away from imported oil by channeling its interests to the SCS. This leads to a scramble to secure potential energy and mineral resources plus the rich fishing grounds of the SCS, motivating claimant states like China to become aggressive in its behavior and leading to increasing tensions and great power competition (Buszynski 2012; Dutton 2011). Meanwhile, other scholars contend that the shifting balance of power also forces the US to balance China's rise through containment strategy, which explains China's more aggressive behavior towards its weaker neighbors and even the US (Ratner 2013). From the point of view of weaker states, particularly with regard to the Philippines, Zhao (2012) contends that the Philippines' strategic hedging with the US and Japan for security on the one hand, and economic dependency on China on the other hand, suggests a dual dependency between the US and China, which will not augur well for improving China-Philippines relations. Only Yee's (2011) argument differs in that it provides a more optimistic conclusion to the issue. According to him, due to the power asymmetry between China and ASEAN, there is a bigger possibility for "give and take" bargaining or compromise between the two because as the larger power, China would want to sustain its regional hegemonic position and thus is prepared to make concessions in order to gather support from the smaller member states of ASEAN and US presence in the region can help augment the negotiations. 


\section{The role of nationalism}

From the domestic political level, nationalism is a factor identified in the literature that drives China's maritime ambitions and becomes more belligerent towards its ASEAN neighbors. China's ascendancy in combination with its humiliated past makes the issue of sovereignty across the SCS a thorny issue especially for the legitimacy of the Chinese Communist Party. According to Dutton (2014: 9), for instance, "extending control over the near seas is the enhancement of security for the Chinese state in conjunction with the healing of a sort of psychological wound in the collective Chinese mind", and asserts that "China's regional maritime strategy appears to have as its aim a reversal of the tectonic shift... a restoration of the regional system to its continental past." Similarly, Yahuda (2013) explains that China's growing assertiveness is due to the growing nationalism stimulated by the country's national leaders. Ross (2009), in the meantime, provides a provocative argument as to the cause of China's maritime ambitions, which is widespread nationalism in Chinese society and the military brass, rather than security, that is the driving force behind its naval buildup. He compares China's maritime policy with continental powers in the past that also engaged in maritime ambitions, and asserts that its naval ambitions will be a litmus paper to test US-China cooperation but at the same time will be constrained by its continental insecurity.

\section{A normative solution through UNCLOS}

Other scholars explore the effects of normative solutions to the disputes through international conventions, particularly the 1982 UN Convention on the Law of the Seas (UNCLOS). One article explores the potential for conflict and cooperation through the UNCLOS and argues that while the UNCLOS is significant in bringing the opportunity for some kind of solution to the SCS disputes, it can also be "missed" and the issue might even get worse (Valencia 1997: 281). Another article, however, argues that the Law of the Seas is important to manage conflicts, if not the solution, among claimant states (Song and Tønnesson 2013).

To synthesize, various scholars have indicated that the changing geopolitical configurations in the Southeast Asian region leads to different responses from the players involved in the SCS conflicts. While China's rise and its aggressive intentions towards its weaker neighbors are key factors identified in the literature for the heightened hostilities, the reaction of other players, particularly from the US and equally the Philippines, also contributes to the spiraling mistrusts, which suggests that a normative solution to the issue will be difficult to attain at the moment. Therefore, understanding the sources of mistrust from each side in asymmetric relationships is essential in order to manage the dilemma, if not find a solution, and maintain the stability of the region.

\section{Analytic framework of asymmetry: the politics of inattention of $A$ and overattention of B}

All state relations in international politics are asymmetric and unequal. It is generally accepted among international relations scholars that asymmetric state relations cause unequal relations among those involved and small states have less choice in their relations to larger ones than the latter has with the relations of the former. While they have different emphases on the causes and consequences the relationship brings about, both 
realists and institutionalists have similar viewpoints on the structure of state relations in asymmetry. Nevertheless, the asymmetry among states does not always result in unequal relations. According to Brantly Womack $(2003,2006)$, the relationship between the larger states and small ones can be translated into mutual acceptance and recognition of communal interests. The obstacle of creating mutual and common interests usually results from the inattention of larger state, $A$, and overattention of small state, $B$, in the related conflicting areas. In asymmetric relations, the larger side, $\mathrm{A}$, can do things to the smaller B that B cannot do in return in contrast to "symmetry," where what A could do to $\mathrm{B}, \mathrm{B}$ might likewise do to $\mathrm{A}$. The asymmetric relations are more likely to cause tension and escalate conflicts because while the larger A has many other concerns aside from the small B, the small B's main concern is the larger A's action. Thus, the small B must be more attentive to actions by the larger A, while the larger A's concern is principally related to the big picture of world affairs. For example, any minor threat from the larger A is critical to the small B, so the larger A and the small B react differently toward each other's actions.

Small B's primary concern in international relations is the fear and worry about assuring national security, while it is merely one of many concerns of the larger A in their asymmetric relations. In the analytic framework of asymmetry, Womack argues that both the larger A and the small B can reach the mutual recognition of common interests by the exchange of what each other needs in their critical and likely unchangeable asymmetric relations. If the larger states in asymmetric relations understand what causes the fear and worries of small ones and in reverse, the small states try to accommodate what the larger ones need, the tension and conflicts caused by asymmetric relations can be managed and reach a solution with less dependence on coercive military forces because even in asymmetric relations the costs of war and military collision are high.

If the outcomes of war and aggressive foreign policies in asymmetric relations cause high costs than those of the negotiation in and management of asymmetric relations, political agents will seek to maintain the asymmetric relations by looking for what they can do for each other's interests. From realists' perspective therefore, asymmetry in international relations is the most crucial international factor that forces small states to choose either balancing or bandwagoning. Although whether small states choose balancing or bandwagoning is contingent on internal and external situations small states face, states are more likely to prefer the less costly to the more costly result. Unlike the dominant wisdom of conventional international relations theories, small states even actively accommodate a large power when they find rationality to create a structure to maximize their interests: security and autonomy. In addition, if political actors could attain an instrument to ensure their interests in domestic politics, the most rational choice of both political agents and actors in asymmetry will be bandwagoning rather than balancing.

Most international relations theorists whose argument underscores the cause of bandwagoning find the bases of rationality mainly from material factors rather than nonmaterial factors such as norms, ideas, identity or culture (Schweller 1994). However, the analytic framework of asymmetry proposes that the larger A can construct a new asymmetric relationship by proving the small B with sustainable leadership over and again in a long-term arrangement. The pivotal point of proving sustainable leadership 
is to ensure security and autonomy of the small B: if the larger A constantly provides the small $B$ with sustainable leadership, the small $B$ will show deference and respect to the larger A. In sum, the small B can assure its security and autonomy with the exchange of deference and respect to the larger A. However, the way the larger A and the small B cooperate in building an international structure to co-exist by confirming mutual interests is still questionable. In other words, when the larger A and the small B fail to construct a reliable arrangement to generate stability and peace based on mutual trust and understanding the asymmetric structure is more likely to keep producing misperception and suspicion.

Another critical factor regarding the difficulty in managing bilateral asymmetric relationship is the global enlargement of asymmetric relations as a consequence of internationally entangled security politics. As the larger A's security concerns become more comprehensive and complicated and accordingly, its security strategy multifaceted, a clear-cut pattern of asymmetry between two countries turns into a convoluted asymmetry relations. For example, a bilateral asymmetric relationship between China and the Philippines in the region of Southeast Asia develops into a triangular asymmetry as the US involves with global security purposes. In the case of the triangular asymmetric relations, the formulation of stable asymmetric relationship will be a more challenging task as the South China Sea disputes display: the Philippines needs to pay attention to not only the China but the US and in a same vein, China should pay attention to the US as well as the Philippines.

Based on the framework of asymmetric analysis proposed by Womack, this paper posits that the current escalating tension between China and the Philippines in the South China Sea disputes is an outcome of the mismanagement of asymmetric relations of both sides. China, the larger A, has failed to ensure the security concern of the Philippines, the smaller $\mathrm{B}$, and the latter has not succeeded in accommodating the former's concern of maintaining geopolitical strategy in the region either. Another variable to account for the worsening relationship between the countries comes from the strategic involvement of the US, which provides an additional source of translating the smaller B, the Philippines' overattention to China's growing influence in the region into overreaction and the larger A, China's inattention to the Philippines into overattention to the agenda. The emphasis on strategic importance of the US in the Asia Pacific area makes the management of asymmetric relation in the regional level a more complicated task to handle and transforms it into a global issue. In sum, the territorial issue that portrays the failure of managing asymmetric relations between China and the Philippines in the South China Sea becomes an icon of clashing interests between two great powers, the US and China, which represents another picture of failing asymmetry relations between a global power and a regional one.

\section{Method and case selection}

This paper illustrates a case study of asymmetry from the point of view of bilateral asymmetry situated in a regional context and extends the model to triangular asymmetry in

a global context. In view of the present challenge of China to the ASEAN region, the Philippines has by far been the most reactive to the issue. In fact, among China's relations with Southeast Asian states having maritime stakes, the Sino-Philippines relations 
has been most adversely affected by the SCS contention. This is all the more surprising because prior to the dispute, their relations had been consistently forthcoming and they do not share any historical burden unlike, for instance, Vietnam.

Adding the US to the China-Philippines asymmetric equation leads to an even more intricate asymmetric relations. The Philippines is one of US' major allies among ASEAN states. Thus, Manila's close relationship with Washington further complicates the former's dealings with Beijing, and it also compounds tensions between Beijing and Washington. As the US draws its attention to the region, China also increasingly worries about the possible restraint to its actions, which can elicit more aggressive intentions and actions. Therefore, the complex but still asymmetric relationship between the US and China and the situation of the Philippines between two big powers creates a pattern of systemic misperceptions of overattention and inattention leading to mismanaged asymmetric relationships.

Paying attention to their interactions and how they lead to a spiral of misperception is crucial to policymakers and analysts from all three countries. As this case demonstrates, asymmetric relations can easily translate into escalating tensions. Disparity in capacity does not automatically render domination or submission; rather, it is the management of asymmetry that would render a more sustainable world order. Thus, the case analyzed here presents some policy implications such as the resumption of track II or informal meetings between the Philippines and China to lessen the tension and rebuild cooperation. By doing so, China and the Philippines can have a route to regularize their relationship and it will lead to harmonizing and stabilizing partnership between the US and China.

\section{Spiral of aggravation between China and the Philippines}

The Spratly group of islands (referred to in China as Nansha, 南沙) is home to over 750 islets and islands, atolls, reefs, and cays in the SCS. China asserts its sovereignty to the whole Spratlys including the 'adjacent waters' or the 12 nautical mile territorial sea from any territorial land including islands. Currently, China occupies seven of the island reefs in the Spratlys. The Philippines, on the other hand, officially maintains sovereignty to eight islands in the Spratly named as the Kalayaan group of islands (KIG, or Freedom Islands), which is formally identified as a municipality of the province of Palawan. Aside from the islands in the Spratlys, both countries are also disputing territorial jurisdiction over the Scarborough Shoal (referred to in Chinese as Huangyan, 黄岩), which is about 500 miles away from the southernmost tip of China and about 100 miles away from the Philippine coast. Despite the two countries' overlapping claims and the 1995 Mischief Reef incident, there have been no major controversies over their contending claims that have negatively affected their overall bilateral relations. However, from 2011 onwards, frictions between China and the Philippines have risen to a new level.

On February 25, 2011, a Philippine fishing boat working close to the Jackson Atoll near the Spratlys was given three warning shots by a Chinese frigate to leave the area as it was in Chinese territorial waters. On March 2, a seismic survey ship working with the Philippine Department of Energy was accosted with intimidation by two Chinese patrol boats along the Reed Bank (referred to as Recto Bank in the Philippines) about 80 nautical miles from the coast of Palawan. The Philippine military present in the area responded 
swiftly by sending two aircrafts and two coastguard vessels to assist the survey vessel. In the wake of these two incidents, the Aquino government further reacted by filing a diplomatic protest to the Chinese Embassy in Manila for the intrusions and by beefing up the AFP's presence in the disputed territorial waters (Storey 2011). Accordingly, the Philippine government asserted that the Reed Bank is well within the country's EEZ and belongs to the KIG, and is therefore not part of the contested areas of the Spratlys. Beijing allegedly brushed away the protest, and a spokesperson of the Chinese Embassy in Manila was quoted saying that "since historical times China has had indisputable sovereignty over the Nansha islands and their adjacent waters".

The year 2011 alone saw a total of nine incidents involving Chinese presence in the contested waters. President Benigno Aquino III thus declared that the AFP's attention should re-focus from internal security to the defense of its territorial and maritime security (de Castro and Lohman 2011). In Aquino's speech during the April 2011 PhilippineUS bilateral military exercises (Balikatan in the Philippines), he announced that more than Php11 billion (US $\$ 283$ million) will be released for the purchase of long-range helicopters and other water crafts to further secure the waters off the Palawan coast. Part of the budget will be sourced from the royalties of the Malampaya natural gas project in Palawan while the rest will come from the AFP modernization fund. ${ }^{3}$ In addition, he announced the Philippine government's acquisition of its first Hamilton-class cutter from the US Coast Guard renamed as the BRP Gregorio del Pilar, and will be followed by two more. Aquino also allotted Php8 billion (US \$183 million) for the deployment and training of naval personnel for oil and gas explorations in Palawan and Mindanao. ${ }^{4}$ AFP Chief General Eduardo Oban Jr. also announced that the AFP's military presence will be sustained in the region starting with the rehabilitation of the Rancudo Airfield in Pagasa Island (Hope Island), the largest among Philippine occupied territories in the Spratlys.

On June 10, 2011, Beijing finally addressed Manila's complaints through the statements released by Chinese Ambassador Liu Jianchao explaining that his government did not commit any intrusions and called on other parties to halt all explorations in areas where China has claims. ${ }^{5}$ Manila, in reaction to Beijing's warning, began to use "West Philippine Sea" for the first time in its official press release. ${ }^{6}$ On June 17, Aquino also declared that the Philippines will not be bullied by China and that Beijing should cease its intrusions, and further adding, "We will not be pushed around because we are a tiny state compared with them"?

In the July 2011 State of the Nation Address (SONA) of President Aquino, he stated that the country is ready to defend its claims in the Spratlys through the acquisition of

\footnotetext{
${ }^{2}$ People's Online Chronicles, March 6, 2011, “China Snub not true-DOE”. http://thepoc.net/index.php/china-snub-nottrue-doe/.

${ }^{3}$ GMA News, April 13, 2011, "Aquino govt to release P11B to acquire more AFP arms, gear". http://www.gmanetwork. $\mathrm{com} /$ news/story/217694/news/nation/aquino-govt-to-release-p11b-to-acquire-more-afp-arms-gear.

4 GMA News, August 31, 2011, "Spratlys feuds fuel Asian arms race and US industry”. http://www.gmanetwork.com/ news/story/230986/news/specialreports/spratlys-feuds-fuel-asian-arms-race-and-us-industry.

5 The China Post, June 10, 2011, "China tells nations to stop Spratly oil searches". http://www.chinapost.com.tw/china/ national-news/2011/06/10/305675/China-tells.htm.

${ }^{6}$ Philippine Daily Inquirer, June 11, 2011, “It's 'West Philippine Sea”. http://newsinfo.inquirer.net/13833/\%E2\%80\%98it\% E2\%80\%99s-west-philippine-sea\%E2\%80\%99.

7 Philippine Star, June 18, 2011, “P-Noy on Spratlys: 'We will not be pushed around”. http://www.philstar.com/ headlines/697155/p-noy-spratlys-we-will-not-be-pushed-around.
} 
more weaponry such as helicopters, more patrol vessels, and other weapons and by elevating the territorial quandary to a UN tribunal. ${ }^{8}$ And in a bold response to the Reed Bank incident, Aquino made clear that the Philippines will defend its territory, in quotes, "There was a time when we couldn't appropriately respond to threats in our own backyard... Now, our message to the world is clear: What is ours is ours". 9 The build-up of tensions in the first half of the year slightly dissipated when President Aquino went on his first official state visit to China from August 30 to September 3. Aquino went to meet his counterpart Chinese President $\mathrm{Hu}$ Jintao for a bilateral meeting to promote economic relations and ease tensions.

In 2012, the hostilities again began to unfold with two incidents: a maritime standoff between the two countries and China's creation of the Sansha City in the Paracels. First, the Philippine Navy surveillance aircraft found eight Chinese fishing boats along the Scarborough Shoal on April 8. The fishing vessels were suspected to be carrying poached giant clams, corals and live sharks on board, and on the same day, the Navy sent the decommissioned BRP Gregorio del Pilar to make inspections on the activities of the fishing vessels. The BRP Gregorio del Pilar tried to apprehend the fishermen on April 10 but were instead obstructed by two Chinese maritime surveillance ships. Two days later, the Philippine ship pulled out from shoal but the standoff remained for another 10-week square off between an outnumbered Philippine vessels versus Chinese maritime vessels working with private fishermen and escorted by the People's Liberation Army Navy (PLAN) just off the horizon.

The Scarborough Shoal tensions also drew nationalistic sentiments from the public on each side. From late April to early May 2012, two university websites from each country, several Philippine government websites, and even a Philippine media website were defaced which started when a suspected hacker from China attacked the University of the Philippines website on April 20. Chinese tour operators also suspended tours to the Philippines and the Chinese government placed stricter quarantines on Philippine banana shipments when it rejected an incoming shipload in early May accused of failing quarantine tests. On May 11, simultaneous protests near the Chinese Embassy in Manila, near the Philippine Embassy in Beijing, and close to the Philippine Consulate in Hong Kong occurred. Finally, through an United States mediation, the two countries promised to withdraw their ships from the disputed shoal. While the Philippines complied and withdrew, China continued its presence at the shoal and built a barrier to the shoal's entrance in July 2012. Since then, Chinese vessels have been patrolling the shoal and turning away Philippine fishing boats through the use of water cannons, the most recent being in April 2015 for which Beijing has consistently denied.

Second, a July 2012 incident further angered not just Manila but also Hanoi when Beijing formally announced the creation of a prefecture level city, Sansha City, in the Paracel Islands, which gives the PLA a definite garrison on the island (Fravel 2014). As Beijing defiantly stood by the Scarborough Shoal, the piled up tensions between China and its smaller ASEAN neighbors including Vietnam, and the added tensions in the Second Thomas Shoal which has been the scene of a cat and mouse game between the two countries since 2014, the Philippine government announced early in January 2013 of its plans

\footnotetext{
${ }^{8}$ See President Benigno S. Aquino III's Second State of the Nation Address, July 25, 2011.

${ }^{9}$ Ibid.
} 
to challenge Beijing's claims by taking it to the International Tribunal for the Law of the Sea (ITLOS). On March 30, 2014, without recourse to a possible backlash from Beijing, Manila forged ahead with the submission of its arbitration document to the Permanent Court of Arbitration in the Netherlands. According to the Philippine Foreign Secretary Alberto del Rosario, the 'memorial' as it is known in the jargon of international arbitration contains more than 40 maps and "nearly 4000 pages" of evidence against China.

The reasons why the maritime disputes in the South China Sea between the two countries have been escalating and of the unlikelihood of resolving the conflicts can be explained in terms of asymmetric perspective. Considering the absolute power disparity between China and neighboring countries in the arena of the SCS, China should have been more cautious and patient to approach the maritime issues. China shares territorial borders with 13 countries and maritime boundaries with six countries including Taiwan. It is assumable that facing the fast rise of an absolute power in the regional context, the border and sea routes sharing countries are more likely to misperceive China's policy as aggressive and expansive based on various repetitive historical observations. In particular, China's current growing state capacity and the features of political regime provide surrounding countries with unprecedented security concerns and the fear of survival. Knowing these worries and concerns, China has emphasized peaceful development, harmonious world, and its contribution to peace and stability in regional and global society. However, China has less understood the causes of Philippines' overattention to China's movements forward the South China Sea. As China misunderstood the failure of managing asymmetric relationship, it becomes a major source of the Philippines' fear and a motivation to provoke stronger nationalistic response in domestic politics particularly among political elites, the bureaucracy, and even among the military; the former's behavior was seen to force the latter to accept power politics and it formulated the escalating spiral of mutual misperception. With the spread of strong nationalism triggered by the China threat, the Philippines was unable to find any strategic option to exit the asymmetric dilemma but looking for another back up to assure its security and autonomy.

\section{The US response to the South China Sea hostilities: shift of asymmetry from bilateral involvement to triangular entanglement}

The SCS hostilities eventually brought the US on its heels to pay closer attention to the developments in the region. Since post-9/11, the US foreign policy security has been concentrated on its war on terror in Iraq and Afghanistan, and US official stand on the SCS issue has been to remain on neutral ground. Two incidents in 2008 and 2009 respectively brought about the US' renewed interest in East Asia (Fravel 2014): 1) China's harrasment of US oil companies working off the Vietnam coast, and 2) China's intimidation of two US naval survey ships along the SCS and East China Sea. Secretary of State Hillary Clinton's statement in the July 2010 ASEAN Regional Forum stressed the US neutrality on the issue, emphasized a "collaborative diplomatic process" and adherence to the principles of international law to solve the disputes, and encouraged all "parties to reach agreement on a full code of conduct". ${ }^{10}$ At the same time, Clinton's statement affirmed US interest to become more involved in the management of the tensions as she

${ }^{10}$ See comments by Secretary of State Hillary Clinton in Hanoi, Vietnam. 2010. 
said, "The US is prepared to facilitate initiatives and confidence building measures consistent with the declaration." ${ }^{11}$ China's Foreign Minister Yang Jiechi gave a quick reaction to Clinton's statement saying that they are "an attack on China". ${ }^{12}$ China also underlined its "core interest" in the SCS, contested the "encirclement" and lambasted US interference in the region. ${ }^{13}$

The US' renewed interest included the shoring up of the longstanding US-Philippine strategic alliance with particular attention to maritime cooperation. A series of bilateral strategic dialogues between the Philippines and the US with the inaugural meeting held in late January 2011 affirmed Washington's support to improve Manila's territorial defense and maritime security. For instance, under the Excess Defense Articles and Foreign Assistance Act of the US, the US approved the Aquino administration's request to purchase three Hamilton class cutters and other US naval equipment to aid in patrolling the Spratly waters. During the first strategic dialogue on November 16, 2011, Hillary Clinton came to Manila and signed the Manila Declaration to commemorate the Philippines-US Mutual Defense Treaty's (MDT) 60th Anniversary. The signing of the declaration reinforces the obligations under the MDT and signifies their agreement to broaden maritime cooperation. On April 30, 2012, in the midst of the Scarborough Shoal intimidations, they held the first United States-Philippines Ministerial Dialogue or "2 plus 2" meetings between their respective top defense officials and diplomats. The dialogue highlighted Washington's commitment to assist the Philippines in achieving a "minimum deterrent posture" alongside an improved maritime security awareness. The ministerial dialogue occurred just right after the conclusion of a joint military exercise held off the coast of Palawan. With Manila's drive to build a "minimum credible deterrence posture" through the purchase of weaponry abroad, the Chinese Foreign Ministry gave a strong warning to the Philippines that its move to involve "a third party" would only "further escalate the situation and even change the nature of the issue". ${ }^{14}$

In June 2012, during the Shangri-La Conference among ASEAN defense ministers in Singapore, US Defense Secretary Leon Panetta confirmed the US foreign policy commitment to make Asia-Pacific its top priority with US rebalancing efforts to Asia through strengthening alliances with key allies such as Japan, South Korea, Philippines, Thailand, and Australia; revitalizing existing partnerships with Singapore and India; and enhancing new ones with Vietnam and more importantly, China. Furthermore, Panetta unveiled the US plans to shift its naval posture between the Pacific to the Atlantic from the current 50/50 percent to a $60 / 40$ split by 2020 . Meanwhile, Panetta's statements were met with caution but with stern conviction in an immediate response from a high ranking official of the PLA explaining that China will take these developments seriously and with vigilance but not lash back. ${ }^{15}$

\footnotetext{
11 Ibid.

12 Chang, Gordon, July 28, 2010, “Hillary Clinton Changes America's China Policy”. http://www.forbes.com/2010/07/28/ china-beijing-asia-hillary-clinton-opinions-columnists-gordon-g-chang.html.

13 BBC News, Bangkok, September 3, 2010, "Why are South China Sea tensions rising?" http://www.bbc.com/news/ world-asia-pacific-11152948.

14 ABS-CBN News, May 23, 2012, “China blasts Philippines' weapons purchase”. http://www.abs-cbnnews.com/depth/05/23/12/china-blasts-philippines-weapons-purchase.

15 Reuters, June 3, 2012, "China to step up vigilance after US Navy focus on Asia Pacific". http://www.ndtv.com/worldnews/china-to-step-up-vigilance-after-us-navy-focus-on-asia-pacific- 486344.
} 
In August 2013, a new round of negotiations began that would allow US forces a forward-deployment position in East Asia by gaining rotational access to Philippine territory. On April 28, 2014, coinciding with President Obama's visit to Manila, the US and the Philippines signed the Enhanced Defense Cooperation Agreement (EDCA) framework. The main purpose of EDCA is to deepen the bilateral defense cooperation and allows an increased presence of the US armed forces in Philippine territory on a rotational basis. The signing of the EDCA is part of Obama's 2014 Asia Trip that reinforces US presence across the Asia-Pacific region and a "broader pledge" to Asia. The signing of the EDCA also drew adverse reaction from one Chinese think tank Wu Shichun as he said that China is "not happy" with EDCA and that it is a way for US to intervene in the region. ${ }^{16} \mathrm{Wu}$ was further quoted saying that the US is "using freedom of navigation as an excuse to interfere in the South China Sea" and to conduct "intelligence activities" along China's coasts. ${ }^{17}$ Obama's visit also drew intense reactions from China's state-run media. China Daily's (2014) Opinion section stated that the "US shows its true colors" with the "new US-Philippines defense agreement, it is increasingly obvious that Washington is taking Beijing as an opponent... it is now clear that Washington is no longer bothering to conceal its attempt to contain China's influence in the region" ${ }^{18}$ In a People's Daily (2014) Editorial section, it reported that an "Emboldened Manila may upset US rebalancing to Asia" with "A more assertive or even reckless Manila would stoke regional tensions". ${ }^{19}$ The opinion piece further explained that "the Philippines has been a trouble-maker in the South China Sea. It has encroached upon Chinese territory and harassed Chinese fishing boats" ${ }^{20}$

From April 20 to 30, 2015, more than 11,000 Filipino and American forces participated and joined by Australian forces in the 2015 Balikatan war exercises, one of the biggest joint military exercise held between the two. The joint military exercise are being held in the midst of China's reclamation activities suspected of constructing airstrips on the Cross Fiery Reef and Subu Reef in the Spratly Islands. The Philippine military, however, dismissed that the show of force is not being targeted against China. In a Global Times (2014) interview with a Chinese analyst, however, he stated that the show of increasing force in the exercises is proof that "the US is pushing its strategy of a pivot to the AsiaPacific and bolstering its allies which are engaged in territorial disputes with China". ${ }^{21}$

The process of US response to escalating tensions in the South China Sea and China's reaction to the US involvement show how the conflicts of bilateral asymmetry between China and the Philippines have transformed to the entanglement of triangular asymmetric conflicts with the US involvement. While the failure of managing asymmetry between China and the Philippines caused the US commitment to the maritime disputation, the exchange of criticisms toward each other between the US and China, US pursuit of joint military exercise with the Philippines to send a clear signal to China, and the following

\footnotetext{
${ }^{16}$ GMA News, September 26, 2014, "EDCA meant to check China, says think tank". http://www.gmanetwork.com/ news/story/380945/news/nation/edca-meant-to-check-china-says-think-tank. 
Chinese reaction to the military drill represent an extended version of the failed management of bilateral asymmetry. As the case of China and the Philippines accounts well for why they could not stop driving each other closer to the point of armed collision, both the US and China find the failure of asymmetry management as a key variable to increase misperception and tension not only in SCS at a regional level but in East Asia at global levels. The US did not accept the role of China as a regional leader and attempted to contain China's try to stretch its interests in the Pacific Ocean. As well, China felt threat from the US strategy to restrain it from seeking naval interests. By building up military capacity with traditional allies and strengthening partnership with other Southeast Asian countries the US clarified its intention and will to confine China within the territory of Asian continent.

In other words, the US commitment to rebalancing Asia policy created a new asymmetric relationship between the larger A, the US, and the smaller b, China, and the military support of the US to assure the Philippines' security and autonomy, in return, made China worry about its security and autonomy. In bilateral asymmetry between China and the Philippines, China less paid attention to the Philippines' security concern and regarded the latter's attention to Chinese behavior as misperception and misunderstanding China's intention. By contrast, in triangular asymmetry, China showed overattention to the US presence in the Asia Pacific and criticized the latter's intention as an intervention to China's domestic affairs. As the bilateral asymmetry becomes triangular asymmetry and political actors become suspicious of each other's intention, the structure of the asymmetric relationship appears to be more complicated and conflict-oriented.

\section{Conclusion}

This paper analyzed the upsurge of the South China Sea disputes from a theoretical framework of asymmetry and discussed how the asymmetric relationship has intensified the misperception between involved countries caused by a changing international environment: the rise of China and the return of the US. In parallel to the shift of international structure, what makes the South China Sea disputes troubled is the international status of the Philippines between the US and China, which features the convolution of asymmetric relations in both regional and global levels. China is a regional power in East Asia and the Philippines is not only China's neighboring country in the region but an ally of the US, a present power in the globe. Thus, the territorial issue between the two countries which presents a regional security issue becomes a flash point in a global context between a potential hegemon, China, and an established hegemon, the US. The triangular asymmetric relationship creates little space between all involved states in finding an exit from the current situation. China needs to prove its leadership in the relationship to the Philippines by assuring the security of the latter but the former more worries about the return of the US with Asia pivot strategy than maintaining a good relationship with the Philippines. The Philippines had better preserve peaceful relationship with China in a regional context but it needs to ascertain its usefulness to the US in the formation of an asymmetric alliance. The US has to confine China to ensure its hegemony mainly due to worries about China's expanding influence in the region and in return, it exacerbates China's concern about its autonomy in the region. 
Unlike half and a decade ago when China had successfully resolved problematic border issues with surrounding countries, the complexity raised by the shifting power relations between the US and China and the wedged status of the Philippines between the two great powers led to the failure of not only Chinese but Filipino foreign policies towards the South China Sea issue. It implies as China grows and increases its influence more the management of the triangular asymmetric relations will be more problematic.

Authors' contributions

ET conceptualized the study and drafted the manuscript. MH also conceptualized the study, developed the theoretical framework and edited the manuscript. Both authors read and approved the final manuscript.

\section{Authors information}

Elaine Tolentino is an Assistant Professor at the International Studies Department, De La Salle University-Manila, Philippines. Her research interests include East Asian security and international relations and Chinese foreign policy. She can be contacted at the following email addresses: elaine.tolentino1@gmail.com or elaine.tolentino@dlsu.edu.ph. Myungsik Ham is an Assistant Professor at the School of International and Public Affairs, Jilin University in China. His research interests include East Asian security and international relations, Chinese politics, and Chinese foreign policy. He can be reached at the following email addresses: myungsikh@gmail.com or myungsikh@jlu.edu.cn.

\section{Author details}

${ }^{1}$ International Studies Department, De La Salle University, Manila, Philippines. ${ }^{2}$ School of International and Public Affairs, Jilin University, Changchun, China.

\section{Compliance with ethical guidelines}

Competing interests

The authors declare that they have no competing interests.

Received: 25 July 2015 Accepted: 20 August 2015

Published online: 02 September 2015

\section{References}

Buszynski, Leszek. 2012. The South China Sea: oil, maritime claims, and US-China strategic rivalry. The Washington Quarterly 35(2): 139-156.

Cha, Victor. 2012. Ripe for rivalry: has Asia's moment of reckoning finally arrived? Foreign Policy Magazine. http://www. foreignpolicy.com/articles/2012/12/12/ripe_for_rivalry

De Castro, Renato. 2014. Linking spokes together: the Philippines' gambit of harnessing the United States' alliances in its external balancing policy against an emergent China. Pacific Focus 29(1): 140-166.

De Castro, Renato and Walter, Lohman. 2011. US-Philippines partnership in the cause of maritime defense. Backgrounder (2593): 1-12.

Dutton, Peter. 2014. China's maritime disputes in the East and South China Seas. Naval War College Review 67(3): 7-18.

Dutton, Peter. 2011. Three disputes and three objectives: China and the South China Sea. Naval War College Review 64(4): 42-67.

Fravel, M. Taylor. 2014. Policy report: U.S. policy towards the disputes in the South China Sea since 1995.

French, Howard. 2014. China's dangerous game. The Atlantic 96-108.

Friedberg, Aaron. 1993/1994. Ripe for rivalry: prospects for peace in a multipolar Asia. International Security 18(3): 5-33.

Glaser, Bonnie. 2012. Armed clash in the South China Sea. Contingency Planning Memorandum No. 14. Council on Foreign Relations, Inc. http://www.cfr.org/world/armed-clash-south-china-sea/p27883

Ratner, Ely. 2013. Rebalancing to Asia with an insecure China. The Washington Quarterly 36(2): 21-38.

Ross, Robert. 2009. China's naval nationalism: sources, projects and the U.S. response. International Security 34(2): 46-81.

Schweller, Randall. 1994. Bandwagoning for profit: bringing the revisionist state back in. International Security 19(1): 72-107.

Song, Yann-Huei, and Stein Tønnesson. 2013. The impact of the law of the sea convention on conflict and conflict management in the South China Sea. Ocean Development and International Law 44: 235-269.

Storey, lan. 2011. China and the Philippines: implications of the Reed Bank incident. China Brief 11(8): 6.

Valencia, Mark. 1997. Asia, law of the Sea and international relations. International Affairs 73(2): 263-282.

Waltz, Kenneth. 1993. The emerging structure of international politics. International Security 18(2): 44-79.

Womack, Brantly. 2006. China and Vietnam: The politics of asymmetry. Cambridge: Cambridge University Press.

Womack, Brantly. 2003/04. China and Southeast Asia: asymmetry, leadership, and normalcy. Pacific Affairs 76(4): 529-548.

Yahuda, Michael. 2013. China's new assertiveness in the South China Sea. Journal of Contemporary China 22(81): 446-459.

Yee, Andy. 2011. Maritime territorial disputes in East Asia: a comparative analysis of South China Sea and East China Sea. Journal of Current Chinese Affairs 40(2): 165-193.

Zhao, Hong. 2012. Sino-Philippines relations: moving beyond South China Sea dispute? The Journal of East Asian Affairs 26(2): 57-76. 